which involves the loss at the power station in flue gases and cooling water of two-thirds of the heat in the fuel. The gas industry uses production processes in which roughly a tenth of the heat in the feedstock is used. Up to 92 per cent of the heat value in the raw material is available in the gas produced". Mr. John Davies, vicechairman of Shell-Mex and B.P., Ltd., read a paper on "The Future of Oil" in which he prophesied that "Thirty years from now the U.K. will be using 200 million tons of petroleum compared with the 61 million tons of today". This was a paper of most exciting forecasts for the oil industry in the years ahead. The picture of the coal industry, as now phased and evolving, was presented by Lord Robens, chairman of the National Coal Board, in his paper on "The Future of Coal"; he said that there was great potential for increasing productivity in the coal industry; that the task of rationalization should be completed by 1970; and that a completely new approach to mining techniques, elimination of uneconomic capacity and increased output from profitable pits were among the modern developments to be reckoned with. "The goal of cheap and abundant supplies of electricity for British homes ... to to be achieved much sooner than most people thought" was the subject of a joint paper "Electricity's Future in the Home-The Complete and Competitive Service" by E. G. Plucknett (Tube Investments, Ltd.) and S. F. Steward (British Electrical and Allied Manufacturers' Association).

\section{Engineering Manpower in Profile}

AN intensive investigation of contemporary American engineering manpower, not without interest and signific. ance in comparable disciplines in the United Kingdom, has resulted in a report from the National Engineers Register, based on responses to a detailed questionnaire sent to a cross-section of engineers in the United States by the Engineers Joint Council, made possible through a contract with the National Science Foundation, entitled Engineering Manpower in Profile (Pp. 30. New York: Engineers Joint Council, 345 East 47th Street, 1965. 1 dollar). More than 57,000 individuals representative of the membership of 41 leading engineering societies returned the required information, revealed by an exhaustive questionnaire (reproduced in this report). "The nation's engineer is a man, median age 41 , who works in industry or is self-employed, and, though he leans towards electronics and work management, may be employed in any of 115 areas of technology. In addition, he and his fellow engineers tend to concentrate in New York and California." Among the pertinent findings of this survey, it is established that: about 71 per cent are employed in industry or self-employed; another 6 per cent work for educational and non-profit institutions; 15 per cent are employed by government; more than 1 out of every 5 engineers possess a doctorate or master's degree; only one-half of one per cent of responding engineers are women; about 42 per cent of the respondents are receiving some degree of support or sponsorship from Federal programmes; and the profession is characterized by its great variety of specialities. The survey has further domonstrated that there is a growing realization that engineering is ". . . the vital element in translating far-ranging scientific discoveries into practical use". This report provides the factual information latterly demanded by industries, educational institutions and Congressional groups in the United States and it is certain to provide a strong basis for guiding and executing many plans and projects now in contemplation in the engineering field in that country.

\section{German Aid to Developing Countries}

THE Overseas Development Institute has published a survey of the sources, policy and structure of German aid to developing countries, aimed at promoting economic development in those countries (German Aid: a Survey of the Sources, Policy and Structure of German Aid. By John White. Pp. 221. London: The Overseas Development Institute, Ltd., 1965. 20s.). Successive chapters of the survey describe the growth and volume of the aid programme, its administrative structure, sources of funds and general policy. Other chapters deal with classification and terminology, bilateral financial assistance, the relations between Germany and other donor countries, problems of private investment, trade, technical assistance in developing countries, and technical and academic programmes in Germany. There are two chapters dealing with technical assistance by non-Government organizations, and with public opinion in Germany. Of 920 German experts overseas on December 31, 1963, 81 were in Europe, 298 in Africa, 439 in Asia and 102 in Latin America. Of the 6,228 technical trainees financed from Federal or Länder funds up to December 31, 1963, 507 were from Europe, 3,277 from Africa north of the Sahara, 1,029 from Africa south of the Sahara, 289 from the Middle East, 414 from Southern Asia, 307 from the Far East, 113 from Latin America and 229 from South America. Of 5,649 Government-sponsored technical trainees up to September 30, 1963, 529 were senior staff, 3,505 engineers, 409 foremen and 1,206 skilled workmen. At the end of the summer term, 1963, there were 27,000 foreign students in Germany, including 18,000 from developing countries, out of a total student body of 370,000 .

\section{Institute of Biology Examinations}

THE Council of the Institute of Biology has approved proposals concerning the examination for membership (Institute of Biology Journal, 2, No. 4; 1964). Courses are designed to last for three years of part-time study and assume a Higher National Certificate in applied biology as the entry requirement. At the end of one year's study a Part 1 examination will be taken in the principal subject, a cognate subject and principles of biology. The remaining two years of the course will be devoted to the special subject, and lead to the Part 2 examination. The special subjects so far approved are biochemistry, entomology, microbiology, pharmacology and plant pathology. Courses are expected to commence in September 1965. It is also reported that, in the summer of 1964, examinations for the Ordinary Endorsed Certificate in Biology were held in 21 centres in England and Wales and Northern Ireland. There were 210 candidates, of whom 156 passed, 36 failed and 18 were referred in one subject. Ten students who had been referred in the Higher Endorsed Certificate in 1963 succeeded in passing the examination in 1964. The first examinations for the Higher National Certificate in Applied Biology were held at 12 colleges in England and Wales. There were 106 candidates, of whom 86 passed, 6 with distinction. One student was referred and 19 failed. In Scotland, courses for the Ordinary National Certificate were offered by five colleges: 83 candidates produced 58 passes, 19 failures and 6 referrals. Six students received distinction or special mention. Two colleges presented candidatos for the Higher National Certificate. Of the 25 entrants, 17 passed, 3 failed and 5 were referred. Three students attempted to add a supplementary subject to their Higher National Certificate, but only one succeeded.

\section{Bee-keeping by John Evelyn}

Over many years John Evelyn (1620-1706) worked at a book treating every aspect of gardens and gardening, with the title Elysium Britannicum. At the time of his death this work was neither finished nor published and the manuscript has since lain in Christ Church, Oxford. One section of this manuscript, probably written in the 1680 's, deals with bees and apiaries, and has now been reproduced in full, together with facsimiles of some of the 